\title{
Editorial: Transitions
}

\section{Peggy Johnson, Editor}

\section{EDITORIAL BOARD}

Editor and Chair

Peggy Johnson

\section{Members}

David Banush, Brown University

Cristopher J. Cronin, University of Chicago

Steven B. Carrico, University of

Florida

Elise Calvi, Indiana Historical

Society

Nadine Ellero, Auburn University

Julian Everett Allgood, New York

University

Andrew S. Hart, University of North Carolina at Chapel Hill

Steven A. Knowlton, University of Memphis

Birdie MacLennan, University of

Vermont

Philip E. Schruer, Stanford

University

Michele Seikel, Okalahoma State

University, Stillwater

Anne M. Sleeman, Community

College of Baltimore County

Catonsville

Lori Terrill, University of Wyoming

Elaine L. Westbrooks, University of Nebraska-Lincoln

Lynn N. Wiley, University of Illinois at Urbana-Champaign

\section{Ex-Officio Members}

Charles Wilt, Executive Director, ALCTS

Alice Platt, Boston Athenæum, Editor, ALCTS Newsletter Online

Norm Medeiros, Haverford College Book Review Editor, LRTS

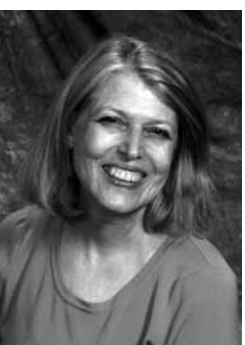

T ibrary Resources and Technical Services (LRTS), the 1 Association for Library Collections and Technical Services (ALCTS) peer-reviewed journal, is supported by an editorial board. The charge to the LRTS board is "to advise the editor on matters relating to editorial policies and journal content, and to assist in the selection of contributors and the evaluation of manuscripts." The success of a scholarly journal depends on its board as much as it does on authors submitting high-quality papers. LRTS board members are responsible for reviewing papers submitted to LRTS. Peer review has a lengthy history dating back to 1665, when the Royal Society implemented the first peerreviewing or refereeing system to evaluate papers submitted to the British Royal Society's Philosophical Transactions of the Royal Society.

LRTS uses a double-blind peer review-the reviewers do not know the names or affiliations of the authors whose manuscripts they are evaluating and authors do not know who the reviewers are. This is to ensure unbiased review.

As editor, I assign papers to board members for review on the basis of their areas of expertise. They evaluate the submission in several areas: relevance to the aims and scope of LRTS, documentation of sources and background information, research methods (if a report of research), and presentation. Reviewers consider the strength and logical structure of the paper and the significance of the topic to the reader. I encourage reviewers to conduct substantive editing and recommend high-level revisions to the content and organization. We aim for a timely response to author; reviewers have three weeks to complete their work, and I try to complete my responsibilities within three weeks of receiving reviews.

Several board members who have been superb paper reviewers and LRTS advisors left the editorial board following the 2012 ALA Annual Conference. They are Allyson Carlyle (Continuing Resources Section representative), Leslie Czechowski (Collection Management Section representative), and members-atlarge Lewis Brian Day, October R. Ivins, Edgar A. Jones, Randy Roeder, Carlen Ruschoff, and Sarah Simpson (all of whom served two two-years terms), and Rebecca L. Mugridge, who completed her one-year term as an intern. All have actively solicited submissions during their tenure. Their diligence and energy will be missed.

Continuing board members are Steven B. Carrico, Steven A. Knowlton, Birdie MacLennan, Anne M. Sleeman, Elaine L. Westbrooks, Elise Thall Calvi (Preservation and Reformatting Section representative), Lori Terrill (Cataloging and Metadata Management Section representative), and Lynn N. Wiley (Acquisitions Section representative). Also continuing on the board are Norm Medeiros (LRTS Book Review Editor) and Alice Platt (ALCTS Newsletter Online Editor).

New members joining the board after the 2012 Annual Conference are Julian Everett Allgood (Continuing Resources Section representative), David Banush, Sian Dorian Brannon (Collection Management Section representative), Christopher J. Cronin, Nadine Ellero, Andrew S. Hart, Philip E. Schreur, Michele Seikel, and Oksana Zavalina (as intern). 
A significant transition will occur during the next six months. Mary Beth Weber has been appointed as the new LRTS editor. Weber is head of central technical services at Rutgers University Libraries and has been a member of ALCTS since 1986. She edited ALCTS Newsletter Online (ANO) from 2004 to 2010 and is the author of four books and many peer-reviewed articles. Weber and I will work closely together until she officially assumes her responsibilities as editor in January 2013.

Fortunately, we do not expect a transition in another position essential to producing an excellent journal. Tim Clifford, our production editor (American Library Association Production Services), ensures that each issue is copyedited and laid out for publication on schedule. He patiently explains nuances of grammar and style that can mystify me. Clifford is now working in both the print world and the digital world as we offer the familiar print journal and the new e-version of LRTS. Please visit the eLRTS website (alcts.metapress.com) if you have not done so. Christine McConnell in the ALCTS office provides us another form of stability. Christine has oversight of ALCTS publications and is ALCTS staff liaison to the editorial board. She has worked diligently to implement eLRTS.

I cannot close my last editorial for LRTS without a few personal observations. "Lately it occurs to me what a long, strange trip it's been." I became LRTS editor in April 2003 and never thought that I would keep that position for more than nine years. I have worked with fabulous editorial board members, outstanding authors, and excellent staff. During my tenure, we implemented an online editorial management system and, recently, eLRTS. I read 367 submissions and shepherded some 45 percent to publication. I learned about the challenges that librarians face and the solutions they are developing, was introduced to new areas of research, and learned from papers written by experts who have challenged our assumptions. But it is time for me to move on "for the times they are a-changin'."

\section{Reference}

1. Association for Library Collections and Technical Services, LRTS Editorial Board, www.ala.org/alcts/mgrps/cmtes/ats-lrts (accessed June 9, 2012).

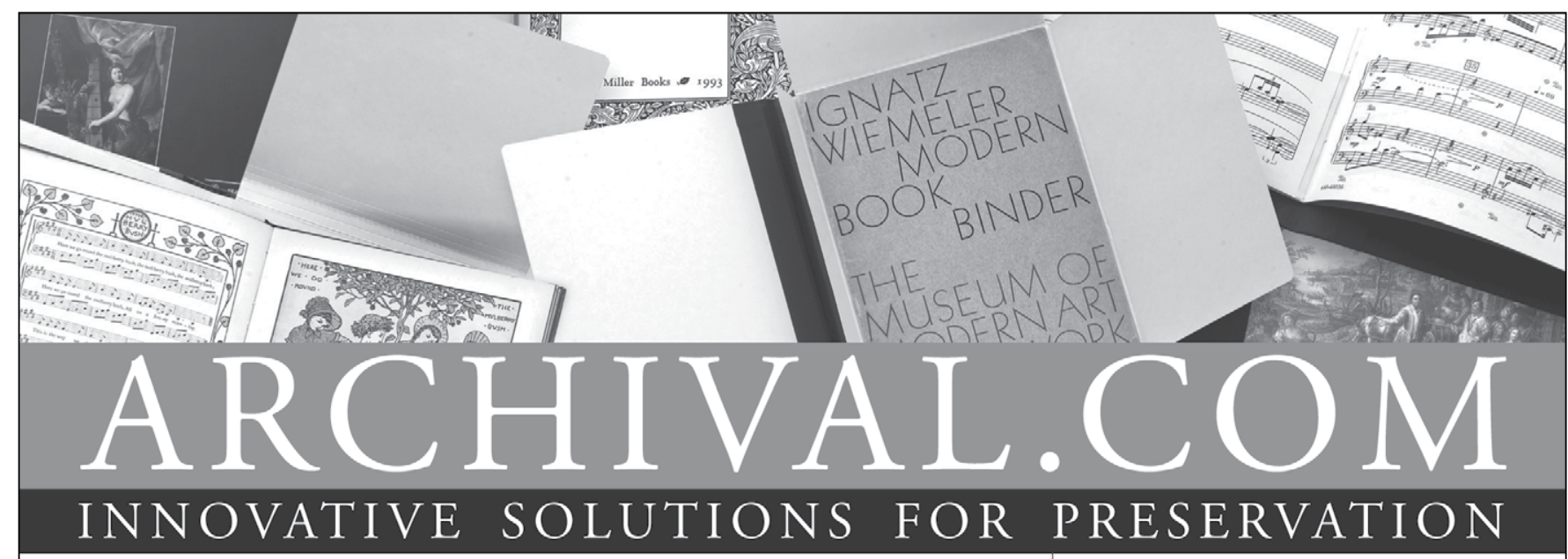

Call for a complete catalog

Pamphlet Binders

Music Binders

Archival Folders

Manuscript Folders

Hinge Board Covers

Academy Folders

Newspaper/Map Folders

Bound Four Flap

Enclosures

Archival Binders
Polypropylene Sheet \& Photo Protectors Archival Boards

Adhesives

Bookkeeper

Century Boxes

Conservation Cloths

Non-Glare Polypropylene

Book Covers

CoLibri Book Cover System

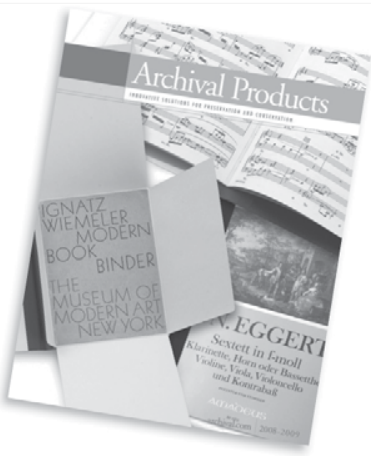

ARCHIVAL PRODUCTS

P.O. Box 1413

Des Moines, Iowa 50306-1413

Phone: 800.526 .5640

Fax: 888.220.2397

E-mail: custserv@archival.com

Web: archival.com 